\title{
Artificial God Optimization - A Creation
}

\author{
Satish Gajawada ${ }^{1,2,3}$ \& Hassan M. H. Mustafa ${ }^{4,5}$ \\ ${ }^{1}$ Alumnus, Indian Institute of Technology Roorkee, Uttaranchal, India \\ ${ }^{2}$ Independent Inventor and Scientist. Founder and Father of Artificial Human Optimization, India \\ ${ }^{3}$ Inventor of Artificial Soul Optimization and Artificial God Optimization, India \\ ${ }^{4}$ Faculty of Specified Education, Department of Educational Technology, Banha University, Egypt \\ ${ }^{5}$ Grand Father of Artificial Human Optimization, Egypt \\ Correspondence: Satish Gajawada, India. E-mail: satish.gajawada.iit@gmail.com
}

Received: December 18, 2019

Accepted: January 6, 2020 Online Published: January 10, 2020

doi:10.5539/cis.v13n1p41

URL: https://doi.org/10.5539/cis.v13n1p41

\begin{abstract}
Nature Inspired Optimization Algorithms have become popular for solving complex Optimization problems. Two most popular Global Optimization Algorithms are Genetic Algorithms (GA) and Particle Swarm Optimization (PSO). Of the two, PSO is very simple and many Research Scientists have used PSO to solve complex Optimization Problems. Hence PSO is chosen in this work. The primary focus of this paper is on imitating God who created the nature. Hence, the term "Artificial God Optimization (AGO)" is coined in this paper. AGO is a new field, which is invented in this work. A new Algorithm titled "God Particle Swarm Optimization (GoPSO)" is created and applied on various benchmark functions. The World's first Hybrid PSO Algorithm based on Artificial Gods is created in this work. GoPSO is a hybrid Algorithm, which comes under AGO Field as well as PSO Field. Results obtained by PSO are compared with created GoPSO algorithm. A list of opportunities that are available in AGO field for Artificial Intelligence field experts are shown in this work.
\end{abstract}

Keywords: artificial gods, artificial god optimization, artificial god computing, computational intelligence, evolutionary computing, particle swarm optimization, genetic algorithms, artificial human optimization, bioinspired computing, nature inspired computing, machine learning, artificial intelligence

\section{Introduction}

John Henry Holland proposed Genetic Algorithms in 1970's (Holland, J. H., 1975). From 1970's to till date, there are hundreds of Nature Inspired Optimization Algorithms proposed in literature. A Research scientist asked on Researchgate the following question in March 2015 (Sandeep Kumar, 2015):

"Question: What are the various Nature Inspired Optimization Algorithms?"

Another Research Scientist replied the following algorithms as answer to the above question (Sandeep Kumar, 2015):

"Answer: The following is the list of various Nature Inspired Optimization Algorithms:

1. Genetic Algorithms (GA)

2. Simulated annealing (SA)

3. Artificial immune systems (AIS)

4. Boids

5. Tabu Search

6. Memetic Algorithm (MA)

7. Ant Colony Optimization Algorithm (ACO)

8. Cultural Algorithms (CA)

9. Particle Swarm Optimization (PSO)

10. Self-propelled Particles 
11. Differential Evolution (DE)

12. Bacterial Foraging Optimization

13. Harmony Search (HS)

14. MBO: Marriage in Honey Bees Optimization

15. Artificial Fish School Algorithm

16. Bacteria Chemotaxis (BC) Algorithm

17. Social Cognitive Optimization (SCO)

18. Artificial Bee Colony Algorithm

19. Bees Algorithm

20. Glowworm Swarm Optimization (GSO)

21. Honey-Bees Mating Optimization (HBMO) Algorithm

22. Invasive Weed Optimization (IWO)

23. Shuffled Frog Leaping Algorithm (SFLA)

24. Central Force Optimization

25. Intelligent Water Drops algorithm, or the IWD algorithm

26. River Formation Dynamics

27. Biogeography-based Optimization (BBO)

28. Roach Infestation Optimization (RIO)

29. Bacterial Evolutionary Algorithm (BEA)

30. Cuckoo Search (CS)

31. Firefly Algorithm (FA)

32. Gravitational Search Algorithm (GSA)

33. Group Search Optimizer

34. League Championship Algorithm (LCA)

35. Bat Algorithm

36. Bumble Bees Mating Optimization (BBMO) Algorithm

37. Eagle Strategy

38. Fireworks algorithm for optimization

39. Hunting Search

40. Altruism Algorithm

41. Spiral Dynamic Algorithm (SDA)

42. Strawberry Algorithm

43. Artificial Algae Algorithm (AAA)

44. Bacterial Colony Optimization

45. Differential Search Algorithm (DS

46. Flower pollination algorithm (FPA)

47. Krill Herd

48. Water Cycle Algorithm

49. Black Holes Algorithm

50. Cuttlefish Algorithm

51. Gases Brownian Motion Optimization

52. Mine blast algorithm 
53. Plant Propagation Algorithm

54. Social Spider Optimization (SSO)

55. Spider Monkey Optimization (SMO) algorithm

56. Animal Migration Optimization (AMO) Algorithm

57. Artificial Ecosystem Algorithm (AEA)

58. Bird Mating Optimizer

59. Forest Optimization Algorithm

60. Golden Ball

61. Grey Wolf Optimizer

62. Seed Based Plant Propagation Algorithm

63. Lion Optimization Algorithm (LOA): A Nature-Inspired Meta heuristic Algorithm

64. Optics Inspired Optimization (OIO)

65. The Raven Roosting Optimization Algorithm

66. Vortex Search Algorithm

67. Water Wave Optimization

68. Collective Animal Behavior CAB algorithm

69. Bumble Bees Mating optimization BBM

70. Flower Pollinated Algorithm

71. Chaos Optimization

72. Wind Driven Algorithm

73. Parliamentary optimization algorithm POA

74. Aritificial Chemical Process Algorithm

75. Aritificial Chemical Reaction Optimization Algorithm

76. Chemical Reaction Algorithm

77. Bull optimization algorithm

78. Elephent herding optimization (EHO)

79. Rain Optimization Algorithm".

From the above answer, we can find that many Nature Inspired Optimization algorithms are proposed in literature till date. However, there is not even a single algorithm that takes God (who created the nature) as Inspiration for creating innovative optimization algorithms. Hence, a new field titled "Artificial God Optimization (AGO)" is invented in this work. AGO field is defined as follows:

Artificial Birds are the basic entities in Particle Swarm Optimization algorithm. Similarly, Artificial Gods are the basic entities in Artificial God Optimization (AGO). All the optimization algorithms, which are proposed based on Artificial Gods, will come under AGO Field. Each Artificial God corresponds to a point in search space. In addition to Artificial Gods, there can be Artificial non-Gods in the population. Each Artificial non-God corresponds to a point in the search space. Artificial non-Gods are less powerful than Artificial Gods.

Details related to God can be found in Ancient Hindu Religious Texts (Veda Vyasa, 3100 BCE) - (Veda Vyasa, 400 BCE - 200 CE). AGO Field concepts are applied to Particle Swarm Optimization (PSO) algorithm to create New AGO Field algorithms. PSO field details are given in articles (Saptarshi Sengupta, Sanchita Basak, \& Richard Alan Peters II, 2018) - (Riccardo Poli, James Kennedy, \& Tim Blackwell, 2007). Articles (Liu H, Xu G, Ding GY, \& Sun YB, 2014) - (Satish Gajawada, \& Hassan M. H. Mustafa, 2019b) show details related to Hybrid PSO Algorithms that are created by modifying PSO algorithm. Till date, there are no Artificial God Optimization Algorithms (AGO Algorithms) proposed in literature. This work makes use of this research gap and invents AGO field.

The rest of the article is organized as follows:

Particle Swarm Optimization algorithm is developed in Section 2. Section 3 presents "God Particle Swarm 
Optimization (GoPSO)". Results are explained in Section 4. Opportunities that are present in AGO Field are detailed in Section 5. Conclusions are given in Section 6.

\section{Particle Swarm Optimization}

Particle Swarm Optimization (PSO) was proposed by Kennedy and Eberhart in 1995 (Kennedy, J., \& Eberhart, R. C., 1995). PSO is based on Artificial Birds. It has been applied to solve complex optimization problems.

In PSO, first we initialize all particles as shown below. Two variables pbest $t_{i}$ and gbest are maintained. pbest $t_{i}$ is the best fitness value achieved by $i^{\text {th }}$ particle so far and gbest is the best fitness value achieved by all particles so far. Lines 4 to 11 in the below Figure 1 helps in maintaining particle best and global best. Then, the velocity is updated by rule shown in line 14 . Line 15 updates position of $i^{\text {th }}$ particle. Line 19 increments the number of iterations and then the control goes back to line 4 . This process of a particle moving towards its local best and also moving towards global best of particles is continued until termination criteria will be reached.

1) Initialize all particles

2) iterations $=0$

3) do

4) for each particle i do

5) If $\left(\mathrm{f}\left(\mathrm{x}_{\mathrm{i}}\right)<\mathrm{f}\left(\right.\right.$ pbest $\left.\left._{\mathrm{i}}\right)\right)$ then

6) pbest $_{i}=x_{i}$

7) end if

8) if $\left(\mathrm{f}\left(\right.\right.$ pbest $\left._{\mathrm{i}}\right)<\mathrm{f}($ gbest $\left.)\right)$ then

9) gbest $=$ pbest $_{i}$

10) end if

11) end for

12) for each particle $i$ do

13) for each dimension $d d o$

14) $v_{i, d}=w^{*} v_{i, d}+$

$$
\begin{aligned}
& \mathrm{C}_{1} * \operatorname{Random}(0,1) *\left(\text { pbest }_{\mathrm{i}, \mathrm{d}}-\mathrm{x}_{\mathrm{i}, \mathrm{d}}\right) \\
& +\mathrm{C}_{2} * \operatorname{Random}(0,1) *\left(\text { gbest }_{\mathrm{d}}-\mathrm{x}_{\mathrm{i}, \mathrm{d}}\right)
\end{aligned}
$$

15) $x_{i, d}=x_{i, d}+v_{i, d}$

16) end for

17) end for

18) iterations $=$ iterations +1

19) while ( termination condition is false)

Figure 1. Particle Swarm Optimization (PSO)

\section{God Particle Swarm Optimization}

The basic entities in the God Particle Swarm Optimization (GoPSO) are Artificial Gods and Artificial non-Gods. Gods can always move in the search space. Whereas non-Gods can move in the search space only if non-God receives blessings of Gods. Based on random number generated and GodProbability, the particle is classified into either Artificial non-God or Artificial God. If a particle is classified as Artificial God then it will update position and velocity irrespective of anything. If particle is classified as Artificial non-God then there are two cases. Based on random number generated and BlessingsOfGodProbability the particle is classified into Blessed nonGod or not blessed non-God. Blessed non-God can move in search space and hence updates velocity and position. Not Blessed non-God cannot move in search space and hence does not update velocity and position.

If the random number generated in line 13 is less than GodProbability, then particle is classified as Artificial God else it is classified as Artificial non-God. Lines 14-17 are executed by God. Lines 19-26 are executed by nonGod. If the random number generated is less than BlessingsOfGodProbability, then the non-God is blessed else it is not blessed non-God. Blessed non-God executes lines 20-23. Hence, velocity and position are updated for Blessed non-God. Line 25 is blank. Therefore, Not Blessed non-God is blocked and does nothing. The same 
procedure is repeated for all particles in first generation.

In second generation, line 13 is again executed. Particle classified as God in first generation can be classified as non-God in second generation. Particle classified as non-God in first generation can be classified as God in second generation. Similarly, in second generation, line 19 is again executed. Therefore, whether non-God receives blessings of God or not is dependent on the random number generated and BlessingsOfGodProbability. The remaining procedure is same as that of first generation.

1) Initialize all particles

2) iterations $=0$

3) do

4) for each particle $i$ do

5) If $\left(\mathrm{f}\left(\mathrm{x}_{\mathrm{i}}\right)<\mathrm{f}\left(\right.\right.$ pbest $\left.\left._{\mathrm{i}}\right)\right)$ then

6) pbest $_{i}=x_{i}$

7) end if

8) if $\left(\mathrm{f}\left(\right.\right.$ pbest $\left._{\mathrm{i}}\right)<\mathrm{f}($ gbest $\left.)\right)$ then

9) gbest $=$ pbest $_{i}$

10) end if

11) end for

12) for each particle i do

13) if ( $\operatorname{random}(0,1)<$ GodProbability ) then //God

14) for each dimension $d$ do

15) $\mathrm{v}_{\mathrm{i}, \mathrm{d}}=\mathrm{w}^{*} \mathrm{v}_{\mathrm{i}, \mathrm{d}}+$

$\mathrm{C}_{1} * \operatorname{Random}(0,1) *\left(\right.$ pbest $\left._{\mathrm{i}, \mathrm{d}}-\mathrm{x}_{\mathrm{i}, \mathrm{d}}\right)$

$+\mathrm{C}_{2} * \operatorname{Random}(0,1) *\left(\right.$ gbest $\left._{\mathrm{d}}-\mathrm{x}_{\mathrm{i}, \mathrm{d}}\right)$

$16 \mathrm{x}_{\mathrm{i}, \mathrm{d}}=\mathrm{x}_{\mathrm{i}, \mathrm{d}}+\mathrm{v}_{\mathrm{i}, \mathrm{d}}$

17) end for

18) else //non-God

19) if ( random $(0,1)<$ BlessingsOfGodProbability) then // Blessed non-God

20) for each dimension $d$ do

21) $\mathrm{v}_{\mathrm{i}, \mathrm{d}}=\mathrm{W}^{*} \mathrm{v}_{\mathrm{i}, \mathrm{d}}+$

$$
\begin{aligned}
& \mathrm{C}_{1} * \operatorname{Random}(0,1) *\left(\text { pbest }_{\mathrm{i}, \mathrm{d}}-\mathrm{x}_{\mathrm{i}, \mathrm{d}}\right) \\
& +\mathrm{C}_{2} * \operatorname{Random}(0,1) *\left(\text { gbest }_{\mathrm{d}}-\mathrm{x}_{\mathrm{i}, \mathrm{d}}\right)
\end{aligned}
$$

22) $x_{i, d}=x_{i, d}+v_{i, d}$

23) end for

24) else // non-God without blessings does nothing

25) end if

26) end if

27) end for

28) iterations $=$ iterations +1

29) while ( termination condition is false)

Figure 2. God Particle Swarm Optimization (GoPSO)

\section{Results}

Benchmark Functions used in this paper are taken from (Optimization Test Functions and Datasets, 2017). The proposed God Particle Swarm Optimization (GoPSO) is applied on Ackley, Beale, Bohachevsky, Booth and Three-Hump Camel functions. Results obtained are compared with PSO. 


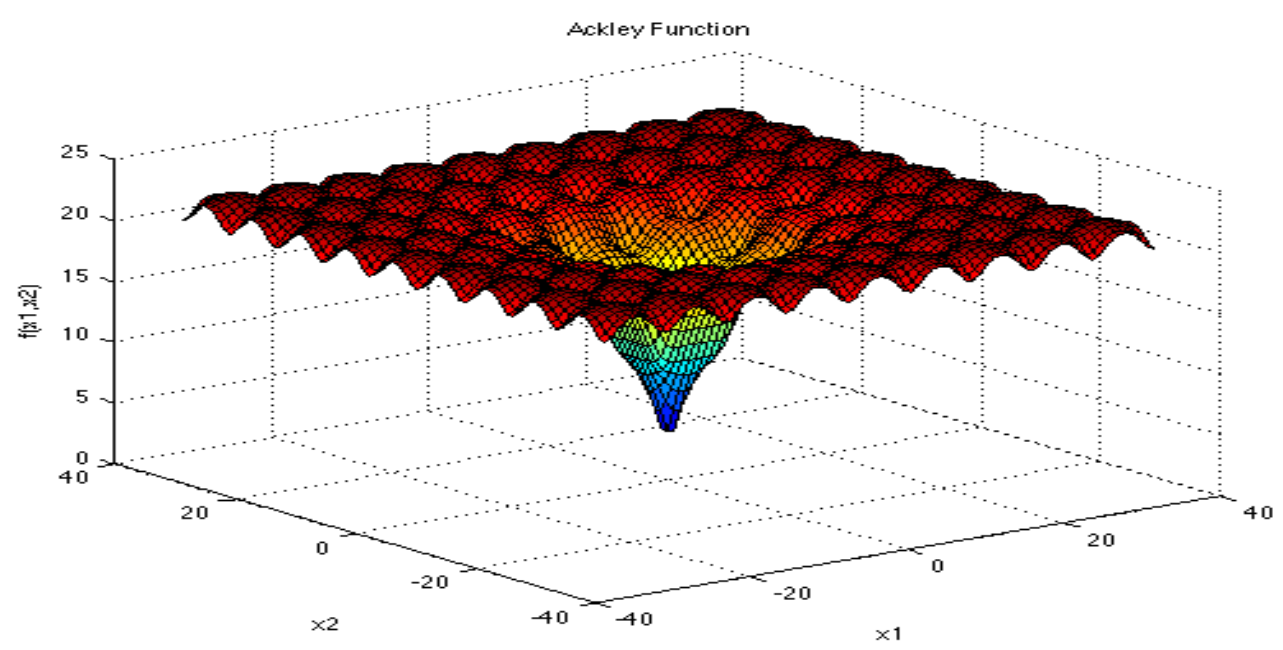

Figure 3. Ackley Function

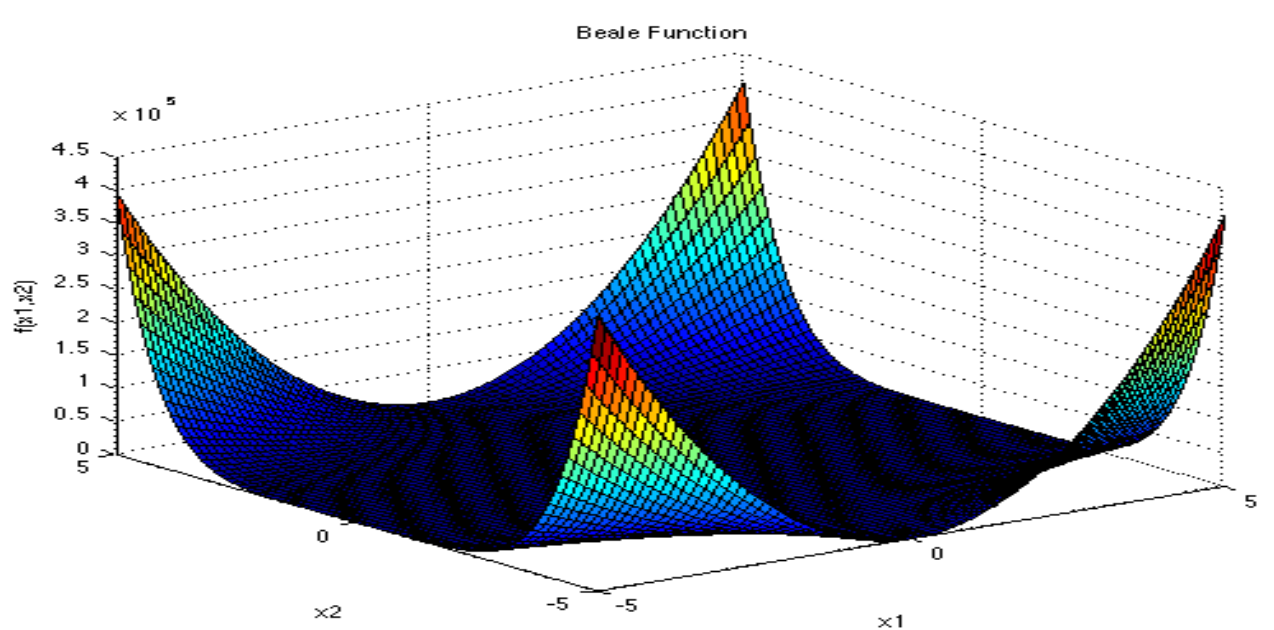

Figure 4. Beale Function

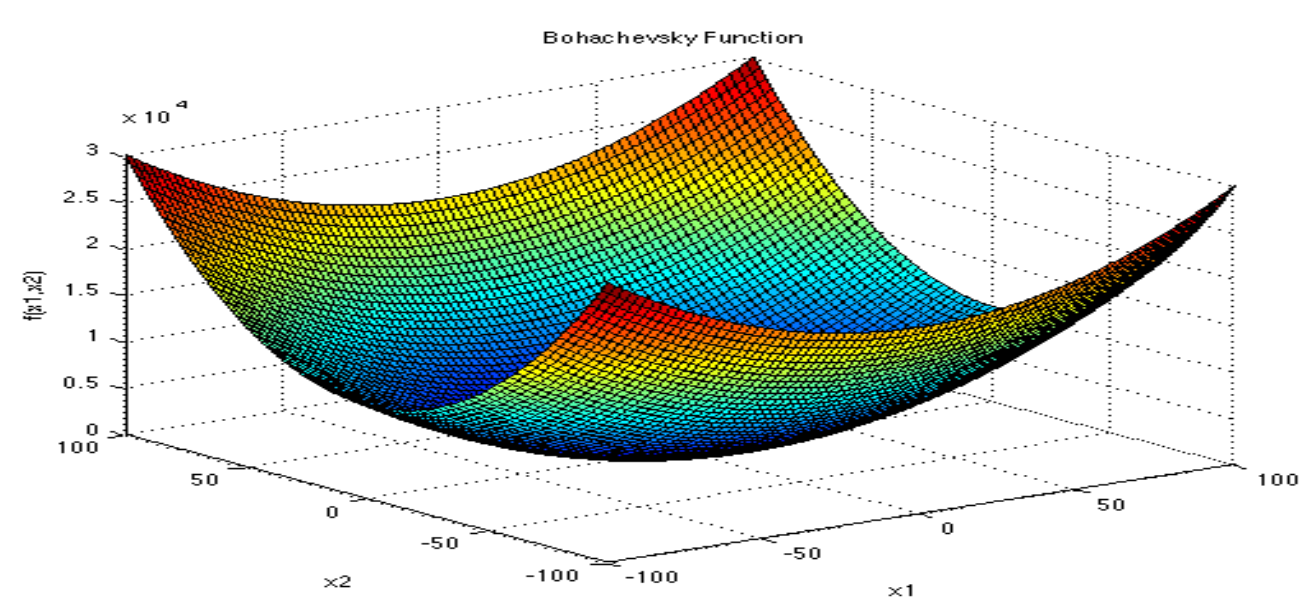

Figure 5. Bohachevsky Function 


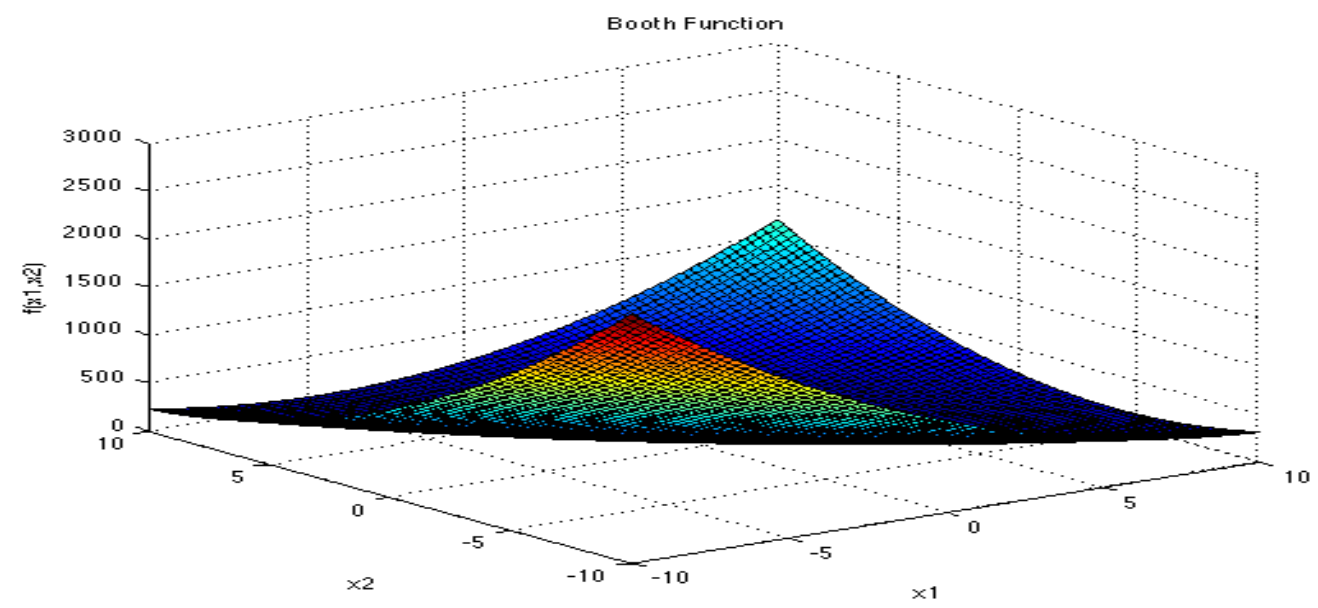

Figure 6. Booth Function

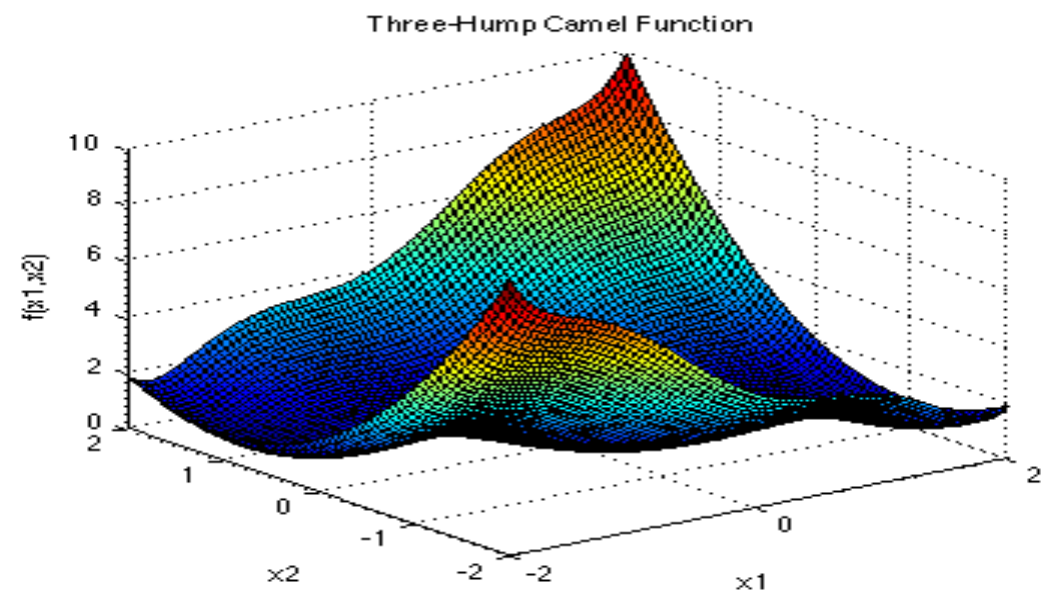

Figure 7. Three-Hump Camel Function

Table 1. Overall Result

\begin{tabular}{|l|l|l|}
\hline Benchmark Function / Algorithm & GoPSO & PSO \\
\hline Ackley Function & & \\
\hline Beale Function & & \\
\hline Bohachevsky Function & & \\
\hline Booth Function & & \\
\hline Three-Hump Camel Function & & \\
\hline
\end{tabular}

In Table 1 Green represents Performed well. Red represents did not performed well. Blue represents performed between well and not well. From Table 1, we can see that both GoPSO and PSO performed well on all benchmark functions.

\section{Interesting Opportunities in Artificial God Optimization Field}

The following are the opportunities in Artificial God Optimization field (AGO field) for experts in Artificial Intelligence field:

1) International Institute of Artificial God Optimization, Hyderabad, INDIA 
2) Indian Institute of Technology Roorkee Artificial God Optimization Labs, IIT Roorkee

3) Foundation of Artificial God Optimization, New York, USA.

4) IEEE Artificial God Optimization Society

5) ELSEVIER journals in Artificial God Optimization

6) Applied Artificial God Optimization - A New Subject

7) Advanced Artificial God Optimization - A New Course

8) Invited Speech on "Artificial God Optimization" in world class Artificial Intelligence Conferences

9) A Special issue on "Artificial God Optimization" in a Springer published Journal

10) A Seminar on "Recent Advances in Artificial God Optimization" at Technical Festivals in colleges

11) International Association of Artificial God Optimization (IAAGO)

12) Transactions on Artificial God Optimization (TAGO)

13) International Journal of Artificial God Optimization (IJAGO)

14) International Conference on Artificial God Optimization (ICAGO)

15) www.ArtificialGodOptimization.com

16) B.Tech in Artificial God Optimization

17) M.Tech in Artificial God Optimization

18) $\mathrm{PhD}$ in Artificial God Optimization

19) PostDoc in Artificial God Optimization

20) Artificial God Optimization Labs

21) To become "Father of Artificial God Optimization" field

\section{Conclusions}

Artificial God Optimization field (AGO field) is invented in this work. A novel God Particle Swarm Optimization (GoPSO) is created in this work. PSO and GoPSO performed well on all benchmark functions. The invented AGO field comes under Artificial God Computing Field. As mentioned in arXiv pre-print, arXiv: 1903.12011 [cs.NE], there is scope for many PhD's and PostDoc's in Artificial Human Optimization field. In addition it is mentioned that there are millions of articles possible in AHO field. Similarly, we can easily prove that AGO field invented in this work has millions of opportunities, which are yet to be explored by Research Scientists across the globe.

\section{Acknowledgments}

Thanks to GOD. Thanks to everyone and everything who directly or indirectly helped us to reach the stage where we are now today.

\section{References}

AlRashidi, M. R., \& El-Hawary, M. E. (2009). A Survey of Particle Swarm Optimization Applications in Electric Power Systems. IEEE Transactions on Evolutionary Computation, 13(4). https://doi.org/10.1109/TEVC.2006.880326

Gajawada, S. (2013). POSTDOC: The Human Optimization. Computer Science \& Information Technology (CS \& IT), CSCP , 3, 183-187. https://doi.org/10.5121/csit.2013.3918

Gajawada, S. (2014). CEO: Different Reviews on PhD in Artificial Intelligence. Global Journal of Advanced Research, 1(2), 155-158.

Gajawada, S. (2016). Entrepreneur: Artificial Human Optimization. Transactions on Machine Learning and Artificial Intelligence, 4(6), 64-70.

Gajawada, S. (2018a). Artificial Human Optimization - An Introduction. Transactions on Machine Learning and Artificial Intelligence, 6(2), 1-9.

Gajawada, S. (2018b). An Ocean of Opportunities in Artificial Human Optimization Field. Transactions on Machine Learning and Artificial Intelligence, 6(3). https://doi.org/10.14738/tmlai.63.4529

Gajawada, S. (2018c). 25 Reviews on Artificial Human Optimization Field for the First Time in Research 
Industry. International Journal of Research Publications, 5(2), United Kingdom.

Gajawada, S., \& Mustafa, H. (2019a). Novel Artificial Human Optimization Field Algorithms-The Beginning. arXiv preprint arXiv:1903.12011.

Gajawada, S., \& Mustafa, H. (2019b). Ten Artificial Human Optimization Algorithms. Transactions on Machine Learning and Artificial Intelligence, 7(3), 1-16. https://doi.org/10.14738/tmlai.75.7322

Gajawada, S., \& Mustafa, H. M. (2018a). Collection of Abstracts in Artificial Human Optimization Field. Collection of Abstracts in Artificial Human Optimization Field, 7(1), 15-15.

Gajawada, S., \& Mustafa, H. M. (2018b). HIDE: Human Inspired Differential Evolution-An Algorithm under Artificial Human Optimization Field. International Journal of Research Publications, 7(1). https://doi.org/10.18488/journal.24.2018.71.18.25

Gajawada, S., \& Mustafa, H. M. (2018c). Artificial Human Optimization - An Overview. Transactions on Machine Learning and Artificial Intelligence, 6(4).

Gajawada, S., \& Mustafa, H. M. (2018d), Testing Multiple Strategy Human Optimization based Artificial Human Optimization Algorithms. Computer Reviews Journal, 1(2).

Gajawada, S., \& Mustafa, H. M. (2018e). Hybridization Concepts of Artificial Human Optimization Field Algorithms Incorporated into Particle Swarm Optimization. International Journal of Computer Applications, 181(19), 10-14. https://doi.org/10.5120/ijca2018917866

Gajawada, S., \& Mustafa, H. M. (2018f). An Artificial Human Optimization Algorithm Titled Human Thinking Particle Swarm Optimization. International Journal of Mathematical Research, 7(1), 18-25. https://doi.org/10.18488/journal.24.2018.71.18.25

Holland, J. H. (1975). Adaptation in Natural and Artificial Systems. University of Michigan Press, Ann Arbor, MI.

Imran, M., Hashim, R., \& Khalid, N. E. A. (2013). An overview of particle swarm optimization variants. Procedia Engineering, 53, 491-496. https://doi.org/10.1016/j.proeng.2013.02.063

Kennedy, J., \& Eberhart, R. C. (1995). Particle swarm optimization. In Proceedings of the IEEE international conference on neural networks IV (pp. 1942-1948). Piscataway: IEEE.

Liu, H., Xu, G., Ding, G. Y., \& Sun, Y. B. (2014). Human behavior-based particle swarm optimization. The Scientific World Journal, 2014. https://doi.org/10.1155/2014/194706

Optimization Test Functions and Datasets. (2017). Retrieved January 3, 2020 from https://www.sfu.ca/ ssurjano/optimization.html

Poli, R., Kennedy, J., \& Blackwell, T. (2007). Particle swarm optimization. Swarm intelligence, 1(1), 33-57. https://doi.org/10.1007/s11721-007-0002-0

Sandeep, K. (2015). Retrieved January 3, 2020 from https://www.researchgate.net/post/What_are_the_latest_Nature_Inspired_Algorithms

Saptarshi, S., Sanchita, B., \& Richard, A. P. I. (2018). Particle Swarm Optimization: A survey of historical and recent developments with hybridization perspectives. https://doi.org/10.3390/make1010010

Saravanan, T., \& Srinivasan, V. (2015). Overview of Particle Swarm Optimization. Indian Journal of Science and Technology, 8(32). https://doi.org/10.17485/ijst/2015/v8i32/87749

Singh, S. (2014). A Review on Particle Swarm Optimization Algorithm. International Journal of Scientific \& Engineering Research, 5(4).

Tang, R. L., \& Fang, Y. J. (2015). Modification of particle swarm optimization with human simulated property. Neurocomputing, 153, 319-331. https://doi.org/10.1016/j.neucom.2014.11.015

Tanweer, M. R., \& Sundaram, S. (2014, April). Human cognition inspired particle swarm optimization algorithm. In 2014 IEEE Ninth International Conference on Intelligent Sensors, Sensor Networks and Information Processing (ISSNIP) (pp. 1-6). IEEE. https://doi.org/10.1109/ISSNIP.2014.6827610

Tanweer, M. R., Suresh, S., \& Sundararajan, N. (2015). Self-regulating particle swarm optimization algorithm. Information Sciences, 294, 182-202. https://doi.org/10.1016/j.ins.2014.09.053 
Tanweer, M. R., Suresh, S., \& Sundararajan, N. (2015, May). Improved SRPSO algorithm for solving CEC 2015 computationally expensive numerical optimization problems. In 2015 IEEE Congress on Evolutionary Computation (CEC) (pp. 1943-1949). IEEE. https://doi.org/10.1109/CEC.2015.7257123

Veda, V. (3100 BCE). Srimad Bhagavatha Purana. Ancient Hindu Religious Text.

Veda, V. (400 BCE - 200 CE). Bhagavad Gita. Ancient Hindu Religiuos Text.

Zhang, Y., Wang, S., \& Ji, G. (2015). A comprehensive survey on particle swarm optimization algorithm and its applications. Mathematical Problems in Engineering, 2015. https://doi.org/10.1155/2015/931256

\section{Copyrights}

Copyright for this article is retained by the author(s), with first publication rights granted to the journal.

This is an open-access article distributed under the terms and conditions of the Creative Commons Attribution license (http://creativecommons.org/licenses/by/4.0/). 